\title{
DEBATE
}

\section{Rastros e restos que interessam: Na pista de uma humanidade encarnada}

Clarice Rios*

Leônia, uma das cidades invisíveis descritas por Italo Calvino, refaz-se inteira a cada dia. Entretanto, nos adverte Calvino:

"mais do que pelas coisas que todos os dias são fabricadas
vendidas compradas, a opulência de Leônia se mede pelas coisas
que todos os dias são jogadas fora para dar lugar às novas. Tanto
que se pergunta se a verdadeira paixão de Leônia é de fato, como
dizem, o prazer das coisas novas e diferentes, ou o ato de expelir,
de afastar de si, expurgar uma impureza recorrente" (1990, p.105).

Leônia se define pelo que nega, "quanto mais Leônia expele, mais coisas acumula." (CALVINO, 1990, p.106)

De forma semelhante, este dossiê também se organiza em torno do que sobra, mais especificamente de "vestígios, restos e substratos corporais", e os modos pelos quais seus fluxos e destinos falam de algo que se procura negar. De acordo com a fórmula Latouriana, o dilema colocado por substratos humanos, cuja liminaridade classificatória remeteria a supostas fronteiras entre "humano" e "não humano", é justamente o da negação do processo de purificação (LATOUR, 1994), que cria e insiste em tais fronteiras. Como se pode constatar nos artigos presentes neste dossiê, essas fronteiras são não apenas arbitrárias, mas profundamente instáveis. Nesse sentido, os artigos de Fonseca e Garrido, Manica, Goldenberg e Asensi, Vassallo e Allebrandt podem ser compreendidas como bem-sucedidos esforços no sentido de etnografar alguns desses processos de purificação. E embora essas etnografias aludam a atores sociais e espaços institucionais atravessados pela lógica e pela prática científica - um laboratório de genética

\footnotetext{
* Clarice Rios é antropóloga, com mestrado pela University of Chicago, doutorado pela University of California - Los Angeles (UCLA), e pós-doutorado em Saúde Coletiva pelo Instituto de Medicina Social (IMS) da Universidade do Estado do Rio de Janeiro (UERJ). Atualmente, é professora substituta no Departamento de Psicologia Social da Universidade Federal do Rio de Janeiro (UFRJ). E-mail: clarice.r@gmail.com.
} 
forense (FONSECA e GARRIDO), arqueólogos (VASSALLO), o Laboratório de Cardiologia Celular e Molecular (MANICA, GOLDENBERG E ASENSI), uma clínica de reprodução assistida (ALLEBRANDT) - falam também dos múltiplos atravessamentos que retiram substratos corporais do status de objeto científico, conferindo-lhes uma agência que é, por vezes, muito mais da ordem do sujeito humano do que de simples objeto da ciência. Esses artigos mapeiam fluxos em que, nos termos de Vassallo, substratos corporais podem ser "objetificados" ou "humanizados". Entretanto, a questão que se coloca a partir daí não é simplesmente da ordem de uma antropologia simétrica - em que a agência é igualmente distribuída entre humanos e não humanos, sujeitos e objetos - mas, como sugere Keane, está "em compreender o modo como as pessoas usam e conferem sentido a palavras e coisas e a agência que lhe atribuem." (2007, p.5) ${ }^{1}$. Conforme argumentarei ao longo deste comentário, ainda que parcialmente, é preciso compreender o modo como a negação dos processos de produção de fronteiras entre humanos e não humanos está relacionada a um certo projeto de humanidade na modernidade.

Aqui, antes de prosseguir no debate, recorro a um argumento desenvolvido pelo antropólogo Webb Keane em uma etnografia sobre o encontro entre missionários calvinistas e os habitantes da ilha de Sumba, na parte Leste da Indonésia, com o intuito de situar melhor meu próprio argumento. A referência é oportuna não pelo tema em si, mas pelo modo como Keane o aborda. Em termos gerais, o livro trata da relação entre linguagem e artefatos materiais, argumentando que o processo de estabelecer relações e fronteiras entre palavras, coisas e sujeitos, está intimamente relacionado à distribuição de agência entre os mesmos. Segundo ele, a atribuição de agência a determinados seres - sejam eles sujeitos humanos, textos ou objetos (entre outras coisas) - é um processo carregado de implicações morais. No livro em questão, por exemplo, Keane entende o suposto fetichismo atribuído aos Sumbaneses como uma forma de atribuir ao outro uma compreensão equivocada de agência. Segundo ele,

“atribuir fetichismo ao outro é acionar uma comparação, na medida que um observador reconhece que alguém está atribuindo um falso valor a objetos. (...) A discussão em torno do fetichismo

\footnotetext{
1 "sorting out how people use and make sense of words and things and their bearings on agency." (KEANE, 2007, p.5)
} 
dirige-se especialmente à atribuição equivocada de agência, responsabilidade e desejo a objetos, que o observador sabe ser apenas matéria morta." (KEANE, 2007, p.179)².

Essa incapacidade é entendida pelos missionários como algo da ordem do erro e da falta de um entendimento racional sobre o mundo, mas, na verdade, reflete a "ideologia semiótica" (KEANE, 2003, 2007) que permeia uma certa narrativa moral da modernidade.

Para desenvolver a noção de ideologia semiótica, Keane retoma a semiótica de Peirce, especialmente no que se refere ao modo como este problematiza a relação entre signo e objeto no signo indicial e no signo icônico. Keane explora uma consequência importante do esquema Peirceano, qual seja, ícones e indexes por si sós não comunicam nada, sua compreensão depende de algumas "premissas básicas sobre o que são sinais e como eles funcionam no mundo" (KEANE, 2003, p.419)3. Segundo Keane, "ideologia semiótica é uma reflexão sobre, e uma tentativa de organizar, as experiências pessoais sobre a materialidade da forma semiótica"4 (2007, p.21). Assim, é a ideologia semiótica que determina e regula, entre outras coisas, quais os possíveis agentes aos quais se pode imputar atos de significação (Só humanos? Embriões? Ossadas?).

O conceito de indexicalidade, por sua vez, é particularmente importante para explorar o papel dos artefatos materiais na economia de representações que regula a relação humano/não humano no âmbito não apenas dos substratos corporais (ossadas, restos humanos, sangue menstrual, embriões e células-tronco), mas também das mediações materiais-indiciárias descritas por Bumachar e Ferreira. Ao contrário dos signos icônicos, cuja representatividade opera através de semelhanças entre signo e objeto, os signos indiciais (ou indexicais) não dependem tanto de relações de semelhança (ainda que convencionais) mas sim de aproximações (também

\footnotetext{
2 "to impute fetishism to other is to set in motion a comparison, as an observer recognizes that someone else is attributing false value to objects. (...) Talk about fetishism is especially concerned with the misattribution of agency, responsibility, and desires to objects, to what the observer knows to be mere dead matter" (KEANE, 2007, p.179).

3 "basic assumptions about what signs are and how they function in the world." (Keane, 2003, p.419)

4 "semiotic ideology is a reflection upon, and an attempt to organize, people's experiences of the materiality of semiotic form" (KEANE, 2007, p.21).
} 
convencionais) entre signo e objeto. Assim, por exemplo, conforme apontam Manica et al., ainda que no contexto do laboratório as células do sangue menstrual ganhem um nome mais neutro (CeSaM) e eventualmente não mantenham nenhuma relação de semelhança com sua proveniência, são associadas continuamente ao sangue menstrual e ao universo de valores e percepções relacionados ao gênero feminino. Como argumentam Fonseca e Garrido (neste volume), o signo indexical (ou indicial) "seria particularmente evocativo, pois reivindica uma realidade arraigada no mundo material."

Mas se em todos os artigos a codificação de agências mais ou menos humanas parece estar ligada às relações de indexicalidade que essas diferentes materialidades engendram, ainda é preciso explicitar melhor os mecanismos de produção de sua humanidade relativa e da instabilidade das fronteiras continuamente (re)desenhadas entre humanos / não humano. Por exemplo, o tratamento dos cadáveres do laboratório de genética forense e dos arqueólogos que pesquisam as ossadas do cemitério dos pretos novos "objetifica" esses substratos corporais, ainda que eles apontem para sujeitos humanos a serem identificados como tais 5 . Como argumenta Crossland, quando transformados em "evidência", a agência desses cadáveres e ossadas passa a residir justamente na sua condição de objetos, na "sua capacidade de "objetar" (LATOUR, 2000, p.115) às histórias, mentiras, ou rumores dito sobre ele: sua agência é a agência secundária e atribuída de um objeto, ao invés daquela de um ser consciente." ${ }^{6}(2009$, p.75)

Todavia, e esse é um dos pontos principais do argumento de Keane, o que organiza e comanda a atribuição de diferentes tipos de agência a objetos científicos, corpos-evidência ou sujeitos humanos, não é sua condição de objeto ou sujeito per se, mas justamente a ideologia semiótica que regula processos de "objetificação" e "humanização". Dito de outra forma, é uma ideologia semiótica historicamente específica que determina o que irá contar como objeto e o que irá contar como sujeito. Para Keane (2003), a noção de

\footnotetext{
${ }^{5}$ Obviamente, esse processo de objetificação não é completo e nem permanente. O caso descrito por Vassallo, do esqueleto semi-intacto descoberto pela equipe de arqueólogos e batizado de Josefina Bakhita, é um bom exemplo das vicissitudes desse processo. Como aponta Vassallo, à Bakhita é atribuído o poder não só de "gritar" e "revelar" coisas, mas também de contribuir para a estabilização do sítio arqueológico como um holocausto negro.

6 "its ability to 'object' (LATOUR, 2000, p.115) to the stories, lies, or rumors told about it: its agency is the secondary and ascribed agency of an object, rather than that of a sentient being."
} 
ideologia semiótica não deve ser tomada como um processo totalizante, sendo, portanto, sujeita a variações, especialmente quanto mais forem atravessadas por diversos tipos de relações indexicais ${ }^{7}$. Mas ele identifica algumas premissas dominantes no que diz respeito ao sujeito humano e sua agência, herdadas principalmente da tradição Protestante (ainda que não restrita a ela), e que compõem o que ele chama de "narrativa moral da modernidade". Segundo Keane, essa "narrativa tende a, geralmente por implicação, associar progresso moral a práticas de distanciamento e reavalição da materialidade." ${ }^{8}(2007$, p.7) Nessa narrativa de emancipação do meio e domínio de si,

“a materialidade das práticas de significação passam a ser identificadas com restrições externas à autonomia dos agentes humanos. Assim, essa materialidade pode, sob alguns aspectos, parecer oferecer uma ameaça à liberdade que exige uma resposta séria. Liberdade, sob essa ótica, parece depender da desmaterialização do que é mais definitivamente da ordem do humano, seja isso entendido como a alma, pensamentos, crenças, ou mesmo, o significado das palavras" (KEANE, 2007, p.7) .

A um só tempo, Keane oferece aqui uma descrição de uma determinada noção de pessoa humana (autodeterminada e livre de afetações externas) e um caminho para compreender a ansiedade gerada pela materialidade das práticas de significação (no livro em questão, problematizada por meio da noção de fetichismo). De acordo com essa lógica (ou ideologia semiótica, para usar os termos de Keane) somos mais humanos o quanto mais pudermos afirmar nossa agência desencarnada, negando com isso

\footnotetext{
${ }^{7}$ Um bom exemplo disso são os microtubos contendo DNA discutidos por Fonseca e Garrido, cujas relações indexicais depende da mediação, uma rede complexa de especialistas e das diversas tecnologias com as quais eles trabalham. Como demonstram Fonseca e Garrido, a materialidade humana da prova evoca respostas muito mais eticamente contundentes do que os tubos de DNA.

8 "the narrative tends, often only by implication, to link moral progress to practices of detachment from and reevaluation of materiality."

9 "the materiality of signifying practices comes to be identified with external constraints on the autonomy of human agents. Thus, this materiality can, in some respects, seem to pose a threat to freedom that demands a serious response. Freedom, in this light, seems to depend on the dematerialization of what is most definitive of humans, whether that be understood as the soul, thoughts, belief, or, say, the meaning of words" (Keane, 2007, p.7).
} 
não apenas determinações externas como também suas bases materiais. No caso dos substratos corporais, estes seriam "mais humanos" o quanto mais pudessem ocultar os diversos agenciamentos materiais que sustentam sua humanidade.

Assim, à semelhança da cidade invisível de Leônia, essa humanidade moderna e supostamente desencarnada, que se acredita continuamente renovável e liberta de determinações alheias a si mesma, se constrói à custa do que procura continuamente ocultar e afastar de si. Nesse caso, não apenas a arbitrariedade e instabilidade das fronteiras traçadas entre humanos e não humanos, mas também as bases nas quais se assentam a concepção dominante de humanidade na modernidade. Vistos sob essa ótica, vestígios, restos, e substratos corporais incomodam não apenas por seu status liminar, mas porque colocam em evidência o que nós, habitantes de uma imensa e invisível Leônia, procuramos negar: somos pó e ao pó voltaremos. As vicissitudes e contradições inerentes a tal projeto de humanidade estão bem ilustradas no caso dos embriões produzidos em uma clínica de reprodução assistida descrita por Allebrandt. Por um lado, o projeto de torná-los mais humanos, para que os pais permaneçam otimistas em relação aos resultados, depende de um esforço e investimento contínuo por parte dos clínicos que, por sua vez, convocam agenciamentos materiais na forma de imagens e números (o chamado Graduate Embryo Score). Mesmo dependendo de todos esses agenciamentos materiais, a "humanidade" é atribuída ao embrião. Tudo deve se passar como se essa humanidade dependesse apenas dele, sendo o papel da tecnologia apenas o de revelar algo que esteve desde sempre ali. Entretanto, quando não há mais interesse em "humanizar" tais embriões, eles se tornam excesso, lixo, material de descarte ${ }^{10}$. Neste momento, trata-se de despi-los de suas dimensões imateriais, formuladas a partir de uma temporalidade orientada para o futuro, e reduzi-los o tanto quanto possível à sua materialidade imanente.

Last, but not least...o artigo de Bumachar e Ferreira trata dessa questão por um viés um pouco diferente dos outros artigos deste dossiê mas, talvez por isso, coloca essa questão de forma ainda mais contundente. No

\footnotetext{
${ }^{10}$ Há obviamente, como descrito por Allebrandt, um caminho alternativo, que seria a doação para a pesquisa com células-tronco. Os diversos fluxos e destinos possíveis para substratos corporais também ilustram a complexidade dos processos de humanização ou objetificação dos mesmos.
} 
caso das presas da Penitenciária Feminina da Capital (PFC, São Paulo), o trabalho de se fazerem presentes na ausência, através de materialidades outras que não a de seus substratos corporais, fala também da inevitável e inescapável dimensão material da agência humana - seja na presença física que possibilita o "contato direto", seja na presença construída através das mediações material-indiciárias. Dito de outra forma, se um componente importante do que se entende por humano remete a um tipo de agência de ordem imaterial - a alma, a interioridade do eu, o pensamento simbólico, entre outros - o imperativo de se fazer presente na ausência expõe o aspecto material de qualquer agência, visto que também depende da materialidade dos "rastros" produzidos por essas presas e seus familiares e dos artefatos tecnológicos que mediam suas relações. Assim, as estratégias de produção de copresença das presas da PFC colocam em evidência o que procuramos sistematicamente negar - somos humanos porque (também) somos matéria ou, nos termos utilizados aqui, temos agência humana porque (também) temos agência material.

Neste momento da história humana neste planeta, no qual a agência humana se faz cada vez mais rarefeita e distribuída, em função das inúmeras mediações sociotécnicas que compõem o tecido da nossa vida diária, ao mesmo tempo que as mudanças climáticas de ordem global expõem as frágeis bases nas quais se assentam a suposta autonomia humana em relação à materialidade da vida, os artigos que compõem este dossiê representam uma necessária e bem-vinda contribuição à reflexão antropológica!

\section{Referências}

CALVINO, Italo

(1990). As cidades invisiveis. São Paulo, Companhia das Letras.

CROSSLAND, Zoe.

(2009). Of clues and signs: Dead bodies and their evidential traces. American Anthropologist, v.111, n.1, p. 69-80.

KEANE, Webb.

(2007). Christian Moderns - Freedom and Fetish in the Mission Encounter. Berkeley / Los Angeles / London, University of California Press.
(2003). Semiotics and the social analysis of material things. Language \& Communication, v. 23, p. $409-425$.

LATOUR, Bruno.

(1994). Jamais fomos modernos. Rio de Janeiro, Ed. 34. 